\title{
PHYSIOLOGICAL AND PATHOLOGICAL ROLES OF GROWTH HORMONE
}

\author{
M. HaRtog, B.A., B.M., B.CH., M.R.C.P. \\ Department of Medicine, Hammersmith Hospital, London, W.12.
}

IT is now more than 40 years since Evans and Long first demonstrated the growthpromoting activity of crude extracts prepared from the anterior pituitary. Since then the hormone responsible has been extracted from the pituitary glands and purified. It has been shown to be a polypeptide and important differences have been demonstrated between growth hormones from different species. Bovine growth hormone, in particular, has been studied intensively, and its physicochemical properties (Ketterer, Randle and Young, 1957) and amino-acid composition (Franklin, Li and Dunn, 1947) have been determined. Modern methods of cyto-chemistry have supported previous circumstantial evidence that, in normal glands, the eosinophil cells of the anterior pituitary are the site of origin of the hormone (Pearse, 1952); and, more recently, the fluorescence of these cells when exposed to an antiserum to growth hormone conjugated with fluorescein, has again confirmed them to be the source of the hormone (Leznoff, Fishman, Goodfriend, McGarry, Beck and Rose, 1960). Russfield, Reiner and Klaus (1956), however, have reported that the predominant cells of the pituitaries from seven acromegalic patients were not eosinophils, but were cells which were only sparsely granular and stained weakly with periodic-acid Schiff (amphophil cells); these cells were presumably secreting growth hormone.

A variety of techniques have been described for extracting the hormone from the pituitary, and as much as $2.7 \mathrm{mg}$. to $5.6 \mathrm{mg}$. has been estimated to be obtained from a single human pituitary (Gemzell and Li, 1959). The hormone is fortunately relatively stable, and can be extracted from pituitary glands which have been stored for months either in acetone or frozen. It has been stated that as much growth hormone can be obtained from adult pituitaries as from those of the young (Gershberg, 1957).

The hormone has widespread metabolic effects, and has an important part to play in the homeostasis of the body's internal environ- ment. It is the purpose of this article to describe briefly the actions of growth hormonf on the metabolism of protein, fat and carbo: hydrate, and then to describe its effects in maraw and its possible pathological roles. For more complete descriptions of its metabolic effecks the reader is referred to reviews by Knobil anf Hotchkiss (1964), Korner (1961a) and Ketterept and others (1957), and for its action in mass to the article by Raben (1962).

\section{Effect on Protein Metabolism}

Lee and Schaffer (1934) performed carcass analyses on rats injected with anterior pituitary extract, and showed them to have higher proc tein and lower fat contents than did the controf animals; conversely Lee and Ayres (1936) showed that hypophysectomised rats on: limited food intake lost more protein and less fat than did control animals on the same det It thus appeared that secretions from the pitus itary had a "protein sparing" action, and when pure growth hormone became available it was soon shown that it produced nitrogen retention with a marked reduction in urine nitroget (Bennett, Li and Laundrie, 1948). An im3 portant feature of this effect of growth hormoneis that it appears to be dependent upon the presence of insulin. Milman, DeMoor and Lukens (1951) showed that growth hormone had no effect on the nitrogen balance of cats which had been pancreatectomised, a smalf effect if the cats were kept on maintenance् doses of insulin, and a normal effect if the dose of insulin was increased during the period of growth hormone administration. Variation of insulin dosage by itself did not alter the nitro․ㅡㄹ. gen excretion.

The exact method whereby growth hormone induces nitrogen retention remains uncertain there is strong evidence for an effect in stimus lating protein synthesis, and it may also have are effect in inhibiting protein catabolism. Mano

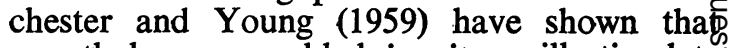
growth hormone added in vitro will stimulate the uptake of radioactive glycine by isolated diaphragm muscle from hypophysectomised rats, and that this is unaffected by the addition? 
of anti-insulin in serum, which will inhibit stimulation produced by insulin. Korner (1961b) in some interesting experiments with cell-free systems, has shown that growth hormone will increase the incorporation of radioactive amino-acids into the ribonucleoprotein microsomal particles of rat liver; these microsomal particles are a site of protein synthesis within the cell.

\section{Effect on Fat Metabolism}

The results of the studies on carcass analyses already mentioned indicated that growth hormone encourages the breakdown of fats within the body, and subsequent work has confirmed this view. Growth hormone will produce a rise of the blood ketone bodies, an increase in the liver fat content, and a fall in the respiratory quotient of the whole animal and of isolated tissues (Greenbaum and McLean, 1953a; Greenbaum, 1953). These, and other experiments, suggested that growth hormone acts by stimulating the utilisation of fats by the liver and peripheral tissues (Greenbaum and McLean, 1953b). However, some subsequent work has failed to support this view. Thus, Franklin and Knobil (1961) studied the oxidation of ${ }^{14} \mathrm{C}$-labelled fatty acids in the rat, and were unable to detect any acceleration after the administration of growth hormone. There is considerable evidence that growth hormone will depress the formation of fats. Welt and Wilhelmi (1950) found that treatment with growth hormone depressed the incorporation of deuterium-labelled water into carcass and liver fats of rats. Goodman (1963) found that the fat content of omental and epididymal fat of hypophysectomised rats was decreased by treatment with growth hormone, and the in vitro synthesis of fat by adipose tissue was diminished. He suggested that the effects of growth hormone on the respiratory quotient and blood ketone bodies mentioned above, could be the result of depressed fat synthesis rather than increased fat oxidation.

Raben and Hollenberg (1959) have shown that growth hormone produces a marked increase in the level of non-esterified fatty acids (NEFA) in the plasma. The NEFAs are liberated from the fat depots and are metabolised further both by the liver and the peripheral tissues; an indication of their rate of utilisation can be obtained from the fact that the half-life of their rate of disappearance from plasma has been estimated as two minutes (Havel and Fredrickson, 1956). Some aspects of their metabolism are reviewed by Fredrickson and Gordon (1958). Raben (1959) has commented upon the very small dose of growth hormone which is required to produce a rise in the plasma NEFA level, suggesting the physiological importance of this action of growth hormone.

\section{Effect on Carbohydrate Metabolism}

Houssay showed that the pituitary has an effect on carbohydrate metabolism when he showed that hypophysectomy would ameliorate diabetes in the dog; in 1949, Cotes, Reid and Young showed that purified bovine growth hormone was diabetogenic in intact adult cats. Hypophysectomised animals are unduly sensitive to insulin, and de Bodo, Kurtz, Ancowitz and Kiang (1950) were able to restore the insulin sensitivity of hypophysectomised dogs to normal with growth hormone. With more prolonged therapy the dogs became insalinresistant and ultimately diabetic.

Young (1945) has emphasised the importance of the response of the beta cells of the islets of Langerhans in detemining the effect of injections of growth hormone. It has already been mentioned that the simultaneous secretion of insulin seems essential for the nitrogenretaining action of growth hormone. There is considerable evidence that growth hormone stimulates the secretion of insulin. Kinash, MacDougall, Evans, Bryans and Haist (1953) found an increase in islet weight after the administration of growth hormone, and rises of serum insulin-like activity have been demonstrated (Randle, 1956; Engel, Albertson, Fredericks and Lopez, 1958). In puppies and kittens "growth hormone administration will stimulate growth, and the animals do not develop diabetes; Young has suggested that these young animals show this effect because they are able to increase their insulin secretion sufficiently. In adult dogs and cats growth hormone will produce a diabetic state during the period of administration (idiohypophyseal diabetes), which may, if the hormone is given long enough, persist even after the injections have stopped (metahypophyseal diabetes). These animals may be unable to increase their insulin secretion adequately, and therefore become diabetic; if irreversible changes are produced in the islets the diabetes will be permanent. By avoiding hyperglycæmia during injections of pituitary extracts, Lukens and Dohen (1942) were able to prevent permanent diabetes; it would therefore appear that it is the persistent hyperglycæmia which is responsible for permanent damage to the islets. The mechanism whereby growth hormone stimulates insulin secretion is uncertain; it may be by 
means of hyperglycæmia or it may represent a direct effect on the islets; the recent demonstration of a rise in pancreatic vein insulin after the infusion of ketone bodies into the pancreatic artery (Madison, Mebane, Ungar and Lochner, 1964) may also be important in this respect.

Administration of growth hormone has been shown by Park, Brown, Cornblath, Daughaday and Krahl (1952) to have a biphasic effect on the glucose uptake of isolated rat diaphragm. Initially, the uptake is stimulated and subsequently it becomes depressed. The initial stimulation may be partly due to the increased insulin secretion, but also is due to a direct effect of growth hormone. Thus, Manchester and Young (1959) showed that growth hormone added in vitro, increased the glucose uptake by isolated rat diaphragm from hypophysectomised animals, and this effect was not inhibited by the addition of an antiserum to insulin. The subsequent period of depression of glucose uptake was not produced by growth hormone in vitro, and so presumably depended upon some transformation or metabolic effect of growth hormone in the body.

The way in which growth hormone depresses glucose uptake has been extensively studied. Colowick, Cori and Slein (1947) found that anterior pituitary extracts produced an inhibition of the enzyme hexokinase, which is concerned with the immediate phosphorylation of glucose, once it has passed the cell membrane, to glucose-6-phosphate, and that insulin reversed this inhibition. More recently Park. Morgan, Henderson, Regen, Cadenas and Post (1961) have studied the regulation of glucose intake in perfused rat heart preparations. The major rate-limiting steps for glucose uptake by muscle are its transport across the cell membrane and its subsequent phosphorylation. The major effect of insulin is the stimulation of transport across the membrane, and growth hormone was shown to have an effect in reducing the sensitivity of this transport system to insulin; growth hormone also caused depression of phosphorylation. In the normal animal, regulation of glucose uptake is provided by the balance between these and other hormones. The insulin sensitivity of the hypophysectomised animal would be understandable on the basis of the effect of insulin in stimulating glucose transport, in the absence of the normal restraining effect of growth hormone on transport and phosphorylation. Another mechanism for the effect of growth hormone on the insulin hypersensitivity of the hypophysectomised animal, was indicated by Alts- zuler, Steele, Dunn, Wall and de Bodo (1959) who used a ${ }^{14} \mathrm{C}$-labelled-glucose dilution tech nique, and found that growth hormone in creased the rate of glucose flow into the plasma, presumably from the liver, in hypophysecto mised dogs.

Williamson and Krebs (1961) found tha疋 acetoacetate decreased the oxidation of glucose by the isolated rat heart, both in the presence and absence of added insulin. Randle, Garo land, Hales and Newsholme (1963), in a stimuss lating paper have shown that ketone bodiess and fatty acids will depress the glucose uptake by isolated rat diaphragm and rat heart. They have suggested that this might provide the mechanism of some of the abnormalities of carbohydrate metabolism found not only after the administration of growth hormone, buf also in diabetes, starvation and after th administration of glucocorticoids. Such \& mechanism would explain the depression of glucose uptake by growth hormone whes administered in vivo but not in vitro.

\section{The Effect on Growth}

Provision of an adequate diet is clearly essen tial for normal growth to occur. Gregn $\vec{c}$ baum (1953) has shown that rats on a limited food intake, when given growth hormone, show an initial growth spurt similar to rats on an unlimited diet also receiving growt th hormone. The increased growth rate in the rats on a restricted diet, however, tailed off as a time which he found to coincide with the depletion of their fat stores by about 50 pe $\overrightarrow{\vec{B}}$ cent. Protein is laid down in muscle with a con 3 siderable amount of water, and its calorific value has been estimated as 1 Cal./g. (Young, 1945)? fat depots, on the other hand, are composed of almost pure fat with a calorific value of $9 \mathrm{Cal} / \mathrm{g}$. Thus, it can be seen how an animas can gain weight even on a restricted food intake if fat is oxidised in preference to protein.

As was discussed in the section on protein metabolism, the simultaneous secretion of in sulin seems essential for the nitrogen-retainin action of growth hormone; it is, therefore, im portant to consider whether insulin itself is responsible for the growth stimulation of growth hormone. Manchester, Randle an\& Young (1959) showed that growth hormone्ठ has the effect of reducing the stimulation of glucose uptake by insulin in the rat diaphragnis insulin thereby perhaps becoming more effective as regards nitrogen retention. Salter and Best (1953) succeeded in maintaining hypophysecs tomised rats on a long-acting insulin, thereb avoiding the effects of hypoglycæmia. The 
found that the insulin-treated animals gained weight; the majority of this weight gain being due to an increased fat content, but there was also a definite rise of body protein. Wagner and Scow (1959) have done similar experiments, and found that force-feeding of hypophysectomised rats produced very similar effects on the weight and body composition as did injections of insulin. In marked contrast was another group of rats treated with growth hormone in whom the excess tissue consisted largely of protein. They concluded that insulin has no specific effect upon growth, other than its effect in stimulating appetite.

\section{The Extraction of Human Growth Hormone}

Once growth hormone from animal sources had been identified and purified it was natural to investigate its activity in man. Though some metabolic changes with such preparations were described, the results were, on the whole, disappointing. Wilhelmi (1955) reported that growth hormone extracted from fish pituitaries was inactive in rats, though it was active in fish, and furthermore, bovine growth hormone was also active in fish. This drew attention to the possibility of the species specificity of human growth hormone (HGH) being responsible for the failure to obtain consistent effects with animal growth hormones in man. $\mathrm{Li}$ and Papkoff (1956) extracted and purified growth hormone from human pituitaries, and showed that it differed in many of its characteristics from bovine growth hormone. Thus, the molecular weight of HGH was estimated as 25,400 and that of bovine growth hormone as 46,000 .

Much work has been done in establishing the composition of $\mathrm{HGH}$, the amino-acid structure of which is described by $\mathrm{Li}$ and Liu (1964). Despite fulfilling many of the physicochemical criteria of a pure substance, HGH when submitted to starch gel electrophoresis gave rise to four distinct lines (Ferguson and Wallace, 1961; Barrett, Friesen and Astwood, 1962). After elution, the material composing these fractions was shown to have the usual metabolic effects of growth hormone when tested in the rat (Ferguson and Wallace, 1961) and in the hypopituitary subject (Laron, Assa and Menache, 1963). Starch-gel electrophoresis has also demonstrated the close similarity in the lines obtained from HGH, and those obtained from preparations of prolactin extracted from sheep and human pituitaries (Ferguson and Wallace, 1961; Barrett and others, 1962). It is, therefore, of particular interest that the purest preparations of HGH have been shown to have lactogenic activity when assayed bio- logically (Chadwick, Folley and Gemzell, 1961), and conversely sheep prolactin has been shown to have growth-hormone-like activity in rats (Reisfeld, Tong, Rickes and Brink, 1961) and to cause nitrogen retention in man (Bergenstal and Lipsett, 1958).

\section{The Effects of Human Growth Hormone in Man}

In 1956, Knobil, Wolf and Green showed that monkey growth hormone was effective in monkeys, and the following year Beck, McGarry, Dyrenfurth and Venning (1957) demonstrated that preparations of monkey and HGH were effective in man. Since then these observations have been repeatedly confirmed, and a number of papers have described the effects of HGH in man (Beck, McGarry, Dyrenfurth and Venning, 1958; Ikkos, Luft and Gemzell, 1959; Clinical Endocrinology Committee of the MRC, 1959; Henneman, Forbes, Moldawer, Dempsey and Carroll, 1960).

The majority of the reports have stated that hypopituitary subjects are more sensitive to the action of HGH than are subjects with a normal endogenous HGH production. A rise of plasma NEFA levels is among the earliest changes after an injection of HGH (Raben and Hollenberg, 1959), the levels rising two- to three-fold above the control levels; a rise of plasma and urine ketones also occurs soon after the administration of $\mathrm{HGH}$. Nitrogen retention is a prominent effect, and the blood urea and urine nitrogen are lowered within 24 hours, the effect of a single injection on urinary nitrogen lasting for approximately ten days. There is a considerable retention of sodium with expansion of the extracellular space; an increased urinary excretion of aldosterone was found by Beck and others (1958) which might have been responsible for this sodium retention. However, others have not found a consistent rise in urinary aldosterone, and the sodium retention occurred in an adrenalectomised patient (Biglieri, Watlington and Forsham, 1961), where it must have been independent of aldosterone secretion. The potassium balance is also positive, even when allowance is made for the retention associated with the laying down of tissue. A surprising feature of the effect of $\mathrm{HGH}$ is the production of a marked hypercalcuria; the intestinal absorption of calcium is usually increased and the overall calcium balance is variable, depending on which of these two effects is the greater. The Clinical Endocrinology Committee of the MRC (1959) have suggested that the increase in urinary calcium may be an over-dosage 
effect of $\mathrm{HGH}$, as doses which produce no further increase in nitrogen retention, showed increased hypercalcuria.

The effects of $\mathrm{HGH}$ on carbohydrate metabolism in man have also been closely studied. The early reports of Beck and others (1958) and Ikkos and others (1959) showed that the administration of $\mathrm{HGH}$ to hypopituitary subjects can produce diminished carbohydrate tolerance, as measured by oral or intravenous glucose tolerance tests. When large doses of HGH were given to two non-diabetic women who had been hypophysectomised for disseminated breast cancer, fasting hyperglycæmia and glycosuria occurred (Ikkos and Luft, 1960). When the HGH injections finished, the carbohydrate tolerance returned to normal. It thus appeared that a state of "idiohypophyseal diabetes" comparable with that found in animals had been produced, and it was interesting that, as was found in animals, a marked positive nitrogen balance occurred despite the development of the diabetic state. Diabetic patients are more sensitive to the "diabetogenic" effect of HGH Three insulin-requiring diabetics who had been hypophysectomised for the treatment of diabetic retinopathy, were given HGH by Luft, Ikkos, Gemzell and Olivecrona (1959); they all showed a pronounced deterioration in their diabetic control with hyperglycæmia, ketonuria and acidosis. In two, the HGH injections had to be stopped after 36 hours. The third patient continued with HGH for 8 days, and, during this time, no appreciable nitrogen retention was noted, again providing a comparison with the animal studies already mentioned, which indicated that increased insulin secretion was necessary for the nitrogen-retaining effect of growth hormone. Administration of $\mathrm{HGH}$ has also been found to be accompanied by an immediate and short-lived period of hypoglycæmia (Zahnd, Steinke and Renold, 1960), during which no rise of insulinlike activity in the blood was found, and must have presumably reflected a direct action of HGH. Rabinowitz and Zierler $(1962,1963)$ have done some interesting experiments in which the metabolism of the forearm was studied by cannulating the brachial artery and the superficial and deep veins of the forearm, (venous samples from the deep vein drain predominantly muscle tissue, and those from the superficial vein mainly adipose tissue). They found that intra-arterial insulin stimulated the uptake of glucose by muscle and adipose tissue and inhibited the release of NEFA from adipose tissue. HGH stimulated the release of NEFA from adipos tissue and stimulated their uptake by muscle tissue; it also inhibited glucose uptake. Whe both hormones were given together or wheninsulin was given to acromegalic subjects, the effect of insulin on glucose uptake was no longer present, though its effect in inhibiting the release of NEFA was unchanged. This evid $\overline{\bar{c}}$. ence, together with evidence obtained frone assays of insulin and assays of HGH in plasm (Roth, Glick, Yalow and Berson, 1963a), leके them to suggest three phases of hormonal res lease action after the intake of food. The first one, immediately after the meal, is dominated, by the effect of insulin and encourages the storage of carbohydrate and fat, the next phase in which both insulin and HGH are effective encourages protein synthesis, and the thirds "remote post-absorptive" phase in which HGH is dominant, results in fat mobilisation.

\section{The Assay of Growth Hormone in Human Serum}

Early methods for the assay of growth hor $\rightarrow \overrightarrow{ }$ mone have depended upon its biological effectso Thus, satisfactory assays have been performed measuring the weight gain of intact or hypo $\overrightarrow{-}$ physectomised rats, and the width of the tibitito epiphyseal cartilage of hypophysectomised rats (Geschwind and $\mathrm{Li}, 1955)$. When applied $\$ 00$ the measurement of $\mathrm{HGH}$ in serum these methods have proved inadequate owing to theiro lack of sensitivity. Gemzell (1959), however developed a technique for the extraction of growth hormone from plasma, and, applyingo this to the tibial epiphysis method, he was able to detect growth hormone-like activity in acro megalic subjects, extracts from normal subjects being inactive. Salmon and Daughadayo (1957) reported a method for the assay. of a "sulphation factor" which stimulated the uptake of radioactive sulphate by costal cartilage from hypophysectomised rats. This "sul-o phation factor" parallelled the expected levels of growth hormone in blood, but could not have been growth hormone itself as this was? found to be inactive in vitro. The assay of the "sulphation factor" has been developed, in iv particular, by Almqvist, who has used it widely in studying hypopituitary subjects and? acromegalic subjects before and after treat $-\omega$ ment (Almqvist, 1961, Almqvist, Ikkos and? Luft, 1961).

Read (1960) developed an immuno-assay for HGH which depended on the "hæmagglutin-" ation-inhibition" technique, in which preparedred blood cells were coated with $\mathrm{HGH}$ and agglutinated by an antibody prepared to $\mathrm{HGH}_{\mathrm{D}}^{\text {? }}$ 
in a rabbit; this agglutination could then be inhibited by solutions containing $\mathrm{HGH}$. The assay is a sensitive one, but unfortunately is affected by factors in serum, probably plasma protein, which interfere with the hæmagglutination (Fraser and Hartog, 1962). The technique has been further elaborated by Dominguez and Pearson (1962) who have used an extraction procedure to remove these interfering substances, and find it to be sensitive and reliable. The methods which are likely to become the most widely adopted are immuno-assays depending on the use of radioactive-labelled $\mathrm{HGH}$. When labelled $\mathrm{HGH}$ is exposed to an antibody to HGH some of it becomes bound to the antibody, and the amount of this binding is affected by the amount of unlabelled $\mathrm{HGH}$ in the system. Hunter and Greenwood (1962) have devised a method for the production of ${ }^{131}$ I-labelled HGH of high specific activity. The different methods which have been developed depend upon different ways of separating the free and the bound HGH (Hunter and Greenwood, 1964a; Glick, Roth, Yalow and Berson, 1963; Utiger, Parker and Daughaday, 1962).

Using these methods most interesting results have been obtained, which have already clarified some of the factors which affect growth hormone secretion. Roth, Glick, Yalow and Berson (1963 a and b) found that the level of serum HGH was raised by fasting, hypoglycæmia and exercise. It would seem that the serum $\mathrm{HGH}$ rises whenever the supply of glucose to the cells is diminished, and perhaps when their glucose requirement increases. The existing methods of assay are not sensitive enough to permit the detection of subnormal values of $\mathrm{HGH}$, but the absence of a rise of serum HGH following the production of hypoglycæmia by insulin or tolbutamide, is likely to be useful in detecting deficient secretion of HGH (Hunter and Greenwood, 1964b).

\section{Pathological Rôles of HGH}

The most obvious rôles of $\mathrm{HGH}$ in disease in man are in states of dwarfism and overgrowth. Dwarfism is a marked feature of hypopituitarism, though such dwarfism does not usually manifest itself until 1-4 years of age (Martin and Wilkins, 1958). The extent to which growth hormone deficiency is responsible for other conditions of dwarfism, in which pituitary function appears otherwise normal, remains uncertain, though it is hoped that the new methods of assay of $\mathrm{HGH}$ will help to clarify them. The so-called primordial or constitutional dwarf would seem unlikely to be the result of growth-hormone deficiency. These children characteristically show retarded growth from birth onwards, and they have failed to show any nitrogen retention following injections of $\mathrm{HGH}$ (Lipsett, Bergenstal and Dhyse, 1961), which raised the possibility of their dwarfism being due to a lack of responsiveness to a normal endogenous production of HGH. Nadler, Neumann and Gershberg (1963) have reported the case of an infant who was severely dwarfed, and who was persistently hypoglycæmic. Tests of thyroid and adrenal function were normal, but the "sulphation factor" in his serum was low. He was given $\mathrm{HGH}$ to which he made a dramatic response both in terms of his growth and his carbohydrate metabolism. Nadler and others have suggested that this infant was suffering from an isolated growth hormone deficiency. With regand to conditions of acromegaly and gigantism, it is to be hoped that the methods of assay of HGH now available should make the assessment of activity of these conditions simpler than it has been to date.

Other pathological conditions in which HGH might be speculated to play some part are the hormone-dependent cancers and diabetes mellitis. Atkins, Falconer, Hayward, MacLean, Schurr and Armitage (1960) showed that hypophysectomy had a slight but significant advantage over adrenalectomy in the treatment of breast carcinomatosis, and it is possible that the factor, the removal of which makes this difference, is $\mathrm{HGH}$. Direct evidence that HGH plays a part in hormone-dependent cancers is difficult to acquire. Pearson and Ray (1959) gave HGH to five women suffering from disseminated cancer of the breast, two of whom complained of bone pain after the injections. However, using the urinary excretion of calcium as a criterion, Lipsett and Bergenstal (1960) were unable to find any effect of $\mathrm{HGH}$.

The occurrence of permanent diabetes in experimental animals following treatment with growth hormone has raised the possibility that HGH may be implicated in the rtiology of diabetes mellitus in man. The incidence of diabetes in acromegaly is known to be raised, and was 17 per cent in Coggeshall and Root's series (1940); this is presumably due to the chronic overproduction of HGH. Some degree of hereditary predisposition seems also to be necessary, as the acromegalics with diabetes have been shown to have a stronger family history of diabetes than do those without diabetes (Coggeshall and Root, 1940). The incidence of big babies among diabetic and pre- 
diabetic mothers has been thought to be possibly due to overproduction of $\mathrm{HGH}$. However Jackson (1954) studied 33 babies from 11 acromegalic mothers and found that their birth weights were not as high as those of prediabetic mothers. Barns and Swyer (1952) injected pregnant rats with anterior pituitary extracts and growth hormone, and were unable to find any unequivocal evidence of an increase in foetal weight under the influence of growth hormone. White (1959) has measured diabetic children within three months of the onset of their symptoms, and found that they exceeded the expected height for their age by about one year. This again invites speculation as to whether growth hormone may be involved.
Luft, Olivecrona, Sjogren, Ikkos and Ljunggre (1954) reported encouraging results after hypoz physectomy for the treatment of severe diabetie complications, and Poulsen (1953) noticed the regression of diabetic retinopathy in a patien who spontaneously developed Simmond 8 disease. Since these reports, the destruction of removal of the pituitary has been performes in several centres as a treatment of diabetio retinopathy (e.g., Hernberg, Bjorkesten and Vannas, 1959; Field, Hall, Contreras an Sweet, 1961; Joplin, Hill, Scott and Fraser 1962), with improvement in some of the features of the retinopathy. Whether the removal of the source of $\mathrm{HGH}$ is the mechan ism of this effect is entirely unknown.

\section{REFERENCES}

AlmQvist, S. (1961): Studies on Sulphation Factor Activity of Human Serum, Acta endocr. (Kbh.), 36, 3f ALMQVIST, S., IKKOS, D., and LUFT, R. (1961): Serum Sulphation Factor in Hypopituitarism and Acromegaly Acta endocr. (Kbh.), 36, 577.

Altszuler, N., Steele, R., DunN, A., Wall, J. S., and DE Bodo, R. C. (1959): Diminution of Insulin Effecte by Growth Hormone in Hypophysectomised Dogs; Studies with C-14 Glucose, Amer. J. Physiol., 196, 23,5

Atkins, H. J. B., Falconer, M. A., HaYward, J. L., MacLean, K. S., SchurR, P. H., and ARMitage, Fe (1960): Adrenalectomy and Hypophysectomy for Advanced Canoer of the Breast, Lancet, $\mathbf{i}, 1148$.

BARNS, H. H. F. and SWYER, G. I. M. (1952): Effects on Fœtal Weights of Growth Hormone-containgn $\vec{B}$

Anterior Pituitary Extracts Given to Pregnant Rats, Brit. med. J., ii, 914.
BARRETT, R. J., FrIESEN, H., and Astwood, E. B. (1962): Characterisation of Pituitary and Peptide Hormones by Electrophoresis in Starch Gel, J. biol. Chem., 237, 432.

Beck, J. C., McGarry, E. E., Dyrenfurth, I., and VenNING, E. H. (1957): Metabolic Effects of Human ăng Monkey Growth Hormone in Man, Science, 125, 884.

Beck, J. C., McGarry, E. E., Dyrenfurth, I., and Venning, E. H. (1958): The Metabolic Effects of Huma and Monkey Growth Hormone in Man, Ann. intern. Med., 49, 1090.

BennetT, L. L., LI, C. H., and Laundrie, B. (1948): Production of Nitrogen Retention in Hypophysectos mised Rats by Small Doses of Hypophysed Growth Hormone, Proc. Soc. exp. Biol. (N.Y.), 68, 94.

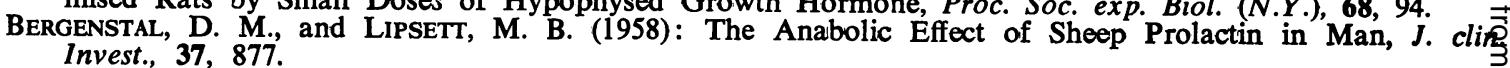

Biglieri, E. G., Watlington, C. O., and Forsham, P. H. (1961): Sodium Retention with Human Growt Hormone and its Subfractions, J. clin. Endocr., 21, 361.

Chadwick, A., Folley, S. J., and Gemzell, C. A. (1961): Lactogenic Activity of Human Pituitary Growt Hormone; Lancet, ii, 241 .

Clinical Endocrinology Committee of the Medical Research Council (1959): The Effectiveness in Mağ of Human Growth Hormone. Lancet, i, 7.

CogGeshall, C., and Root, H. F. (1940): Acromegaly with Diabetes Mellitus, Endocrinology, 26, 1.

Colowick, S. P., CoRI, G. T., and SLEIN, M. W. (1947): The Effect of Adrenal Cortex and Anterio Pituitary Extracts and Insulin on the Hexokinase Reaction, J. biol. Chem., 168, 583. Cores, P. M., REID, E, and Young, F. G. (1949): Diabetogenic Action of Pure Anterior Pituitary Growt
Hormone, Nature (Lond.), 164, 209.

DE BODO, R. C., KurTz, M., ANCowitz, A., and KiANG, S. P. (1950): Anti-Insulin and Diabetogenic Actions of Purified Anterior Pituitary Growth Hormone, Amer. J. Physiol., 163, 310. DomingUeZ, J. M., and PEARSON, O. H. (1962): Immunological Measurement of Growth Hormone in Huma
Sera, J. clin. Endocr., 22, 865. ENGEL, F. L., ALBERTSON, T., Fredericks, J., and LoPEZ, E. (1958): Evidence for Stimulation of Insuling

Ferguson, K. A., and Wallace, A. L. C. (1961): Prolactin Activity of Human Growth Hormone, Natur乡 (Lond.), 190, 632.

Field, R. A., Hall, W. A., Contreras, J. S., and Sweet, W. H. (1961). Hypophyseal Stalk Section in the Treatment of Advancing Diabetic Retinopathy, New Engl. J. Med., 264, 689.

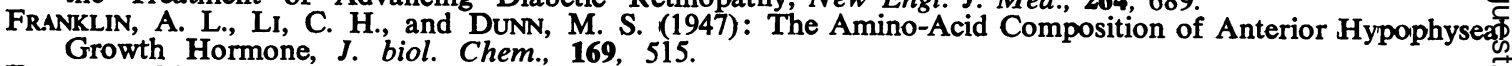

FrANKLIN, M. J., and KNOBIL, E. (1961): The Influence of Hypophysectomy and Growth Hormone Adminisi tration on the Oxidation of Palmitate-I-C-14 by the Unanxsthetised Rat, Endocrinology, 68, 867. FraSER, R., and HARTOG, M. (1962): Immunological Studies with Human Growth Hormone, Ciba Found
Coll. Endocrinology, 14, 105. 
Fredrickson, D. S., and Gordon, R. S. (1958): Transport of Fatty Acids, Physiol. Rev., $38,585$.

Gemzell, C. A. (1959): Demonstration of Growth Hormone in Human Plasma, J. clin. Endocr., 19, 1049.

Gemzell, C. A., and Li, C. H. (1959): Estimation of Growth Hormone Content in a Single Human Pituitary, J. clin. Endocr. 18, 149.

GerSHBERG, H. (1957): Growth Hormone Content and Metabolic Actions of Human Pituitary Glands, Endocrinology, 61, 160.

Geschwind, I. I., and LI, C. H. (1955): The Tibia Test for Growth Hormone, in 'Hypophyseal Growth Hormone: Nature and Actions', pp. 28-51. New York: McGraw-Hill.

Glick, S. M., Roth, J., Yalow, R. S., and BerSON, S. A. (1953: Immuno-assay of Human Growth Hormone in Plasma, Nature (Lond.), 199, 784.

Goodman, H. M. (1963): Effect of Chronic Growth Hormone Treatment on Lipogenesis by Rat Adipose Tissue, Endocrinology, 72, 95.

Greenbaum, A. L. (1953): Changes in Body Composition and Respiratory Quotient of Adult Female Rats Treated with Purified Growth Hormone, Biochem. J., 54, 400.

Greenbaum, A. L., and McLean, P. (1953a): Mobilisation of Lipid by Anterior Pituitary Growth Hormone, Biochem. J., 54, 407.

Greenbaum, A. L., and McLean, P. (1953b): The Influence of Pituitary Growth Hormone on the Catabolism of Fat, Biochem, J., 54, 413.

HAVEL, R. J., and FredrickSON, D. S. (1956): The Metabolism of Chylomicra: I. The Removal of Palmitic Acid-I-C-14 Labelled Chylomicra from Dog Plasmá, J. clin. Invest. 35, 1025.

Henneman, P. H., Forbes, A. P., Moldawer, M., Dempsery, E. F., and Carroll, E. L. (1960): Effects of Human Growth Hormone in Man, J. clin. Invest., 39, 1223.

Hernberg, C. A., Buörkesten, G., and Vannas, S. (1959): Hypophysectomy in the Treatment of Retinopathy and Nephropathy in Severe Juvenile Diabetics, Acta Endocr. (Kbh.), 31, 241.

Hunter, W. M., and Greenwood, F. C. (1962): Preparation of Iodine-I-131 Labelled Human Growth Hormone of High Specific Activity, Nature (Lond.), 194, 495.

HunTeR, W. M., and GREenwOOD, F. C. (1964a): A Radio-immunoelectrophoretic Assay for Human Growth Hormone, Biochem, J., 91, 43.

HunTeR, W. M., and GReENwOOD, F. C. (1964b): Studies on the Secretion of Human Pituitary Growth Hormone, Brit. med. J., 1, 804.

Ikkos, D., LufT, R., and Gemzell, C. A. (1959): The Effect of Human Growth Hormone in Man, Acta Endocr. (Kbh.), 32, 341.

Ikkos, D., and LUFT, R. (1960): 'Idiohypophyseal' Diabetes Mellitus in Two Hypophysectomised Women, Lancet, ii, 897.

JACKSON, W. P. U. (1954): The Prediabetic Syndrome. Large Babies and the (pre)Diabetic Father, J. clin. Endocr. 14, 177.

Joplin, G. F., HILL, D. W., Scott, D. J., and Fraser, R. (1962): Pituitary Ablation in the Treatment of Diabetic Retinopathy, in 'Disorders of Carbohydrate Metabolism', pp. 207-217. London: Pitman.

KetTerer, B., Randle, P. J., and Young, F. G. (1957): The Pituitary Growth Hormone and Metabolic Processes, Ergebn. Physiol., 49, 127.

Kinash, B., MacDougall, I., Evans, M. A., Bryans, F. E., and Haist, R. E. (1953): Effects of Anterior Pituitary Extracts and of Growth Hormone Preparations on the Islets of Langerhans and the Pancreas, Diabetes, 2, 112

KNobil, E., Wolf, R. C. and Greep, R. O. (1956): Some Physiological Effects of Primate Pituitary Growth Hormone Preparations in the Hypophysectomised Rhesus Monkey, J. clin. Endocr., 16, 916.

KNoBIL, E., and HotchKiss, J. (1964): Growth Hormone, Ann. Rev. Physiol., 26, 47.

KORNER, A. (1961a): Growth Hormone, in 'Modern Trends in Endocrinology', pp. 19-43. London: Butterworths.

KORNER, A. (1961b): The Effect of Hypophysectomy and Growth Hormone Treatment of the Rat on the Incorporation of Amino-Acids into Isolated Liver Ribosomes, Biochem. J., 81, 292.

LARon, Z., AsSA, S., and Menache, R. (1963): Metabolic Activity of Individual Electrophoretic Fractions of Human Growth Hormone, J. clin. Endocr., 23, 315.

LeE, M. O., and SCHAFFER, N. K. (1934): Anterior Pituitary Growth Hormone and the Composition of Growth, J. Nutr., 7, 337.

LEE, M. O., and AYRES, G. B. (1936): The Composition of Weight Lost and the Nitrogen Partition of Tissues after Hypophysectomy, Endocrinology, 20, 489.

Leznofp, A., Fishman, J., Goodfriend, L., MCGarry, E., BeCK, J., and Rose, B. (1960): Localisation of Fluorescent Antibodies to Human Growth Hormone in Human Anterior Pituitary Glands, Proc. Soc. exp. Biol. (N.Y.), 104, 232.

Li, C. H., and PAPKoff, H. (1956): Preparation and Properties of Growth Hormone from Human and Monkey Pituitary Glands, Science, 124, 1293.

LI, C. H., and LIU, W. K. (1964): Human Pituitary Growth Hormone, Experientia, 20, 169.

LIPSETT, M. B., and BERGENSTAL, D. M. (1960): Lack of Effect of Human Growth Hormone and Ovine Prolactin in Carcinoma in Man, Cancer Res., 20, 1172.

LipSETT, M. B., Bergenstal, D. M., and DHYSE, F. G. (1961): Metabolic Studies with Human Growth Hormone in Dwarfism and Acromegaly, J. clin. Endocr., 21, 119.

Luft, R., IKKos, D., Gemzell, C. A., and Olivecrona, H. (1959): The Effect of Human Growth Hormone in Hypophysectomised Human Diabetic Subjects, Acta Endocr. (Kbh.), 32, 330.

Luft, R., Oliverrona, H., Siogren, B., IKKos, D., and LJungGren, H. (1954): Therapeutic Results of Hypophysectomy in Metastatic Cancer of the Breast and in Severe Diabetes Mellitus: Adrenocortical Function after Hypophysectomy, Ciba, Found. Coll., Endocrinology, 8, 438.

Lukens, F. D. W., and DoHEN, F. C. (1942). Pituitary Diabetes in the Cat; Recovery Following Insulin or Dietary Treatment, Endocrinology, 30, 175. 
Madison, L. L., Mebane, D., Ungar, R. H., and Lochner, A. (1964): Evidence of Stimulatory Feedbacke of Ketones on Pancreatic Beta Cells, J. clin Invest., 43, 3.

Manchester, K. L., and Young, F. G. (1959): Hormones and Protein Biosynthesis in Isolated Rat Dia-Z phragm, J. Endocr., 18, 381.

Manchester, K. L., RANDle, P. J., and Young, F. G. (1959): The Effect of Growth Hormone and of Cortisole on the Response of Isolated Rat Diaphragm to the Simulating Effect of Insulin on Glucose Uptakeand on Incorporation of Amino-Acids into Protein, J. Endocr., 18, 395.

Martin, M. M., and Wilkins, L. (1958): Pituitary Dwarfism: Diagnosis and Treatment, J. clin. Endocr., 18, 679.

Milman, A. E. DeMoor, P., and Lukens, F. D. W. (1951): Relation of Purified Pituitary Growth Hormoneo and Insulin in Regulation of Nitrogen Balance, Amer. J. Physiol., 166, 354.

Nadler, H. L., NeumanN, L. L., and Gershberg, H. (1963): Hypoglycæemia, Growth Retardation and Prob-布 able Isolated Growth Hormone Deficiency in a One-Year-Old Child, J. Padiat., 63, 977.

Park, C. R., Brown, D. H., Cornblath, M., Daughaday, W. H., and Krahl, M. E. (1952): The Effect of Growth Hormone on Glucose Uptake by the Isolated Rat Diaphragm, J. biol. Chem., 197, 151 .

Park, C. R., Morgan, H. E., Henderson, M. J., Regen, D. M., Cadenas, E., and Post, R. L. (1961): $: \overrightarrow{0}$ The Regulation of Glucose Uptake in Muscle as Studied in the Perfused Rat Heart, Recent Progr: Hormone Res., 17, 493.

Pearse, A. G. E. (1952): Cytochemical Localisation of the Protein Hormones of the Anterior Hypophysis:Ciba Found. Coll. Endocrinology, 4, 1.

Pearson, O. H., and RAY, B. S. (1959): Results of Hypophysectomy in the Treatment of Metastatic Mam 3

mary Carcinoma, Cancer (Philad.), 12, 85.
Poulsen, J. E. (1953): Houssay Phenomenon in Man: Recovery from Retinopathy in a Case of Diabetes with Simmond's Disease, Diabetes, 2, 7.

Raben, M. S., and Hollenberg, C. H. (1959): Effect of Growth Hormone on Plasma Fatty Acids, J. clin. Invest., 38, 484.

RABEN, M. S. (1959): Human Growth Hormone, Recent Prog. Hormone Res., 15, 71.

RABEN, M. C. (1962): Growth Hormone, New Engl. J. Med., 226, 31, 82.

RABINOWITZ, D., and ZIERLER, K. L. (1962): Acute Effects of Human Growth Hormone on Forearm Metabolism in Man, Clin. Res., 10, 402.

RABINOWITZ, D., and ZIERLER, K. L. (1963): A Metabolic Regulating Device Based on the Actions of Human Growth Hormone and of Insulin, Singly and Together, on the Human Forearm, Nature (Lond.) 199, 913.

RANDLE, P. J. (1953): The Influence of Growth Hormone on Blood Insulin and Glycogen Activity, in 'Hypo $\vec{\theta}$ physeal Growth Hormone: Nature and Actions', pp. 413-437. New York: McGraw-Hill.

Randle, P. J., Gari.and, P. B., Hales, C. N., and Newsholme, E. A. (1963): The Glucose Fatty-AGid Cycle, Lancet, i, 785.

ReAD, C. H. (1960): The Immunologic Assay of Human Growth Hormone, Clinical Endocrinology, I, pp 598-605. New York: Grune and Stratton.

Reisfeld, R. A., TONG, G. L., Rickes, E. L., and BrinK, N. G. (1961): Purification and Characterisationo of Sheop Prolactin, J. Amer. chem. Soc., 83, 3717.

Roth, J., GLICK, S. M., YALOW, R. S., and BERSON, S. A. (1963a): Secretion of Human Growth Hormone: Physiologic and Experimental Modification, Metabolism, 12, 577.

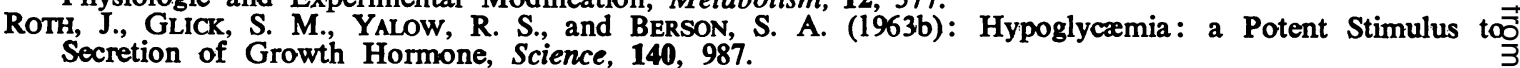

RusSFIELD, A. B., REINER, L., and KLAUS, H. (1956): The Endocrine Significance of Hypophyseal Tumours? in Man, Amer. J. Path., 32, 1055.

SAlMON, W. D., and DAUGHADAY, W. H. (1957): A Hormonally Controlled Serum Factor which Stimulates Sulphate Incorporation by Cartilage in vitro, J. Lab. clin. Med., 49, 825 .

SALTER, J., and BEST, C. H. (1953): Insulin as a Growth Hormone, Brit. med. J., ii, 353.

Utiger, R. D., Parker, M. L., and DaughadaY, W. H. (1962): Studies on Human Growth Hormone, Ió A Radio-Immuno-Assay for Human Growth Hormone, J. clin. Invest., 41, 254.

WAGNER, E. M., and Scow, R. O. (1957): Effect of Insulin on Growth in Force-fed Hypophysectomised Rats, Endocrinology, 61, 419. WeLT, I. D., and WILHELMI, A. E. (1950): Effect of Adrenolectomy and of Adrenocorticotrophic and Growth?
Hormones on the Synthesis of Fatty Acids, Yale J. Biol. Med., 23, 99.

WHITE, P. (1959): Diabetic Children and their Later Lives, in 'Treatment of Diabetes Mellitus', pp. 655-690.D London: Henry Kimpton.

Wilhelmi, A. E. (1955): Comparative Biochemistry of Growth Hormone from Ox, Pig, Horse and Fish Pitui taries, in 'The Hypophyseal Growth Hormone: Nature and Actions', pp. 59-69. New York: McGraw-Hill, N

Williamson, J. R., and KREBS, H. A. (1961): Aceto-Acetate as Fuel of Respiration in the Perfused Rat Heart, Biochem. J., 80, 540 .

YouNG, F. G. (1945): Growth and Diabetes in Normal Animals Treated with Pituitary (Anterior Lobe) Diabetogenic Extract, Biochem. J., 39, 515.

ZAHND, G. R., SteINKe, J., and ReNOLD, A. E. (1960): Early Metabolic Effects of Human Growth Horre mone, Proc. Soc. exp. Biol. (N.Y.), 105, 455. 